\title{
Marco Goldoni and Christopher McCorkindale (eds.), Hannah Arendt and the Law
}

\author{
Wout Cornelissen
}

\begin{abstract}
Marco Goldoni and Christopher McCorkindale (eds.), Hannah Arendt and the Law (Oxford and Portland, NY: Hart, 2012), 362 .
\end{abstract}

Within law and legal theory, Hannah Arendt is probably best known for having coined the following two phrases: 'the right to have rights' and 'the banality of evil.' She uses the first in the ninth chapter of her book The Origins of Totalitarianism, entitled 'The Decline of the Nation-State and the End of the Rights of Man', in which she offers her account of and response to the rise of stateless people in post-World War I Europe. The chapter in question has become an important reference point for those who work in the fields of public international law and migration law. She coined the second phrase in her book Eichmann in Jerusalem, her controversial report of and response to the trial of Adolf Eichmann. This book has become an important source for those who work in the field of international criminal law especially.

Precisely in the rare instances where Arendt seems to postulate the existence of a 'right' (as in the case of 'the right to have rights') or where she issues her own 'verdict' (as in the Eichmann case), lawyers and legal theorists are eager to generalize her observation or judgment into a systematic theory which she herself 'failed' to develop. It is important to bear in mind, however, that Arendt herself did not think like a lawyer or legal theorist in this sense, let alone like a lawgiver. This does not mean that she does not have meaningful things to say about the law, or that her work may not somehow be relevant for lawyers. It does mean that her observations and judgments need to be read within the context of her oeuvre as a whole - an oeuvre which can probably best be characterized as a tentative but persistent attempt to develop a phenomenological understanding of human action and thought. In particular, Arendt draws attention to both the disclosing and distorting role of language in understanding concrete political events and experiences and in opening up and keeping alive the very possibility of political action.

Thanks to the pioneering work of, amongst others, Jeremy Waldron (2000), Jan Klabbers (2007), and Christian Volk (2010), there has been a growing interest in Arendt's thinking about the law throughout her whole oeuvre, especially The Human Condition and On Revolution. The edited volume Hannah Arendt and the Law claims to build on this development. It is presented by its editors as 'the first dedicated and systematic (if not comprehensive) treatment of the many, various and interesting things which Arendt had to say on the law and legal processes, and in so doing somehow to find law's place within the broader scope of her political thought' (p. 1). By asking Arendt-scholars 'what does Arendt say about 
the law?' and by asking lawyers 'what might Arendt's work say to the law?', the volume hopes to 'spark a dialogue' between them (p. 1).

The bulk of the volume consists of the conference proceedings of a workshop that was organized under the same title at the University of Antwerp in June 2010. These twelve contributions have been supplemented by six other pieces, three of which are new (Klabbers, Charles Barbour, and James Bohman), and three of which were published before (William Smith, Seyla Benhabib, and Patricia Owens). The eighteen chapters are preceded by a brief foreword by Richard Bernstein and an introduction by the editors. Three chapters offer a comparative approach (Vivian Liska on Giorgio Agamben, Kari Palonen on Karl Jaspers, and Benhabib on Raphael Lemkin). The arrangement of the chapters into four different 'parts' seems somewhat artificial, as there are very few cross-references and several chapters touch upon multiple aspects of Arendt's work. It is largely up to the reader, therefore, to discover meaningful connections between the various pieces and stage a dialogue between them.

The opening chapter by Keith Breen is devoted to an examination of Arendt's critique of the Hebrew-Christian conception of the law as command and her exploration of two alternatives: the Greek concept of nomos (the law as boundary) and the Roman concept of lex (the law as relationship). According to Breen, Arendt wrongly suggests that the law can altogether be purged from moments of violence and exclusion. He notes that in The Human Condition, she herself describes the drawing of the boundaries of the polis as a pre-political act, and he claims that she ignores the fact that every relationship necessarily excludes others. In his view the root cause of Arendt's failure lies in her strict separation of the political sphere as the realm of freedom from the non-political spheres of the household and of 'the social' as the realms of necessity. His critique is similar to that of Emilios Christodoulidis and Andrew Schaap, who in their chapter express their concern that Arendt's distinction between the political and the social leads to the exclusion of social issues from political contestation. Unfortunately, these critiques are by no means new - think, for instance, of Alan Keenan (1994) and Jacques Rancière (2004) respectively - and they are based on a propositional rather than a performative understanding of her thought.

Of all contributors, Klabbers is the only one who raises the important methodological question of how to make Arendt's work speak to the law while (or rather, by) doing justice to her own way of thinking. He starts by noting: 'It has become rather fashionable to explore contemporary political issues by invoking the works of Hannah Arendt, and often this takes the form of starting with Arendt's thoughts on some topic or other, finding that her thoughts leave a few gaps, filling in those blanks, and then somehow hoping that the speculating is enough in line with what Arendt said and wrote to make it plausible' (p. 229). Rather than using her work as 'a fount of wisdom,' he considers it as 'a source of inspiration.' More specifically, he starts with her focus on the uses of language, that is, on 'the unspoken assumption that language is rarely neutral but often already steers discussion and debate into a certain direction, or, more importantly still, comes to function as a blanket, warming its users but obscuring relevant issues and opinions from view' (p. 230). He then fruitfully employs this approach by analyzing 
the way in which current-day human rights discourse, insofar as it is under the influence of the largely neo-liberal terminology of 'global governance,' tends to take away our common responsibility for refugees and migrants, rather than encouraging people to act. Similarly, Arendt's articulation of 'the right to have rights,' that is, the right to be part of a political community, a space in which one's actions and opinions actually matter, serves to reveal the political idleness of a lot of 'unalienable human rights' talk.

In his chapter, Charles Barbour presents the compelling thesis that, for Arendt, a right is not so much a property or possession, but rather the capacity to act. He adds that this capacity is both an ontological given - it is given by the fact of being born - and a performative achievement - it requires and coincides with the creation of a space of appearance. Hence, he argues that 'the right to have rights' should not be read as a moral claim to membership (as Benhabib does elsewhere), for this potentially transforms it into a passive experience of being recognized, and thus renders it politically neutral. Moreover, he claims against Rancière and Schaap (in an earlier piece) that the capacity to act is not necessarily confined to any formally constituted political and legal domain, but always potentially breaks through the boundaries of such domains.

In their chapters, James Bohman and Samantha Besson read Arendt in the ways criticized by Klabbers and Barbour. Bohman attributes to Arendt the claim that 'the right to have rights' is identical to the right to membership of a state, and he then goes on to assert that this merely restates the problem of today's illegal immigrants, rather than providing a solution for them. He understands her to be a 'republican' who 'derives' the possession of rights from the status of being a citizen, whereas he believes it ought to be 'derived' from the universal status of being a person instead, not realizing that he thereby ends up using the kind of discourse Arendt criticizes in the first place. Besson recognizes that Arendt was not interested in providing any such philosophical justification of human rights, but she nevertheless employs a 'republican' reading of Arendt to develop her own understanding of human rights as both legal and moral rights. Moreover, her claim that 'the right to have rights' (understood as 'the right to membership') ought to be legalized internationally and that 'having rights' (understood as 'member's rights') ought to be legalized nationally, has little to do with Arendt.

Due to its lack of a 'systematic treatment' and the varying quality of its chapters, this volume is not the important work of reference it could have been. As a whole, it fails to explicitly articulate, evaluate, and bring into dialogue the radically different ways in which Arendt's work is read and used. Yet, despite its shortcomings, the volume contains several individual contributions that are worthwhile reading, for Arendt-scholars and legal theorists alike, especially insofar as they demonstrate how Arendt's thought may help us think about the performative effects of certain forms of legal discourse and encourage us to open up the possibility of action and assume responsibility for the world. 